\title{
Arsenic removal from waste water by ozone oxidation combined with ferric precipitation
}

\author{
N.Otgon, G.Zhang*, C.Yang \\ Key laboratory of green process and engineering, Institute of Process Engineering, \\ Chinese Academy of Sciences, Beijing 100190, China
}

ARTICLE INFO: Received: 27 June, 2016; Revised: 02 Oct, 2016; Accepted: 19 Oct, 2016

\begin{abstract}
The oxidation of $\mathrm{As}(\mathrm{III})$ to $\mathrm{As}(\mathrm{V})$ followed by precipitation and adsorption is thought to be the most effective process for removal of arsenic in industrial wastewater. In this work, the oxidation of As(III) to As(V) with ozone was carried out in an acidic solution. After oxidation, arsenic was removed by precipitation in an iron (III) sulfate system under ambient pressure at $90^{\circ} \mathrm{C}$ in acid. Batch experimental results show that ozone is quite effective in oxidizing As(III) at low $\mathrm{pH}$. And more than $90 \%$ of $5 \mathrm{~g} / \mathrm{l} \mathrm{As}(\mathrm{III})$ was removed from the acidic solution by precipitation with $\mathrm{Fe}_{2}\left(\mathrm{SO}_{4}\right)_{3}$ in $7-8$ hours.
\end{abstract}

Key words: Arsenate, Arsenite, Ozone, Oxidation, Precipitation

Copyright $\odot 2016$ Otgon N, et al. This is an open access article distributed under the Creative Commons Attribution 4.0 International License CC BY, which permits unrestricted use, distribution, and reproduction in any medium, provided the original work is properly cited.

\section{INTRODUCTION}

Recently, the toxic behavior of arsenic is receiving increased attention as the arsenic pollution has been reported worldwide. Arsenic is a common element which is widely distributed throughout the rock, soil, natural water and marine environments and associated with some base and precious metals in the sulfide ores [1-3]. Hereupon, the mining and metallurgical industries have expended considerable research efforts to develop environmentally acceptable methodologies for the arsenic removal from waste water. Under natural conditions As is mostly found in inorganic forms as trivalent arsenite (As(III)) or as oxyanions of pentavalent arsenate $(\mathrm{As}(\mathrm{V}))$. In comparison with $\mathrm{As}(\mathrm{V}), \mathrm{As}(\mathrm{III})$ is high mobile and more difficult to be removed from the aqueous solution. All of the arsenic precipitation work carried out involved both ferric iron and pentavalent arsenic in solution, based on the substantially correct premise $[2,4]$. It is necessary to oxidize the trivalent arsenic to its pentavalent state before the arsenic removal. A lot of researchers focused on the methods for oxidation of $\mathrm{As}(\mathrm{III})$ to $\mathrm{As}(\mathrm{V})$ using different oxidants [5-7,8]. In several studies, ozone applications have been reported for treatment of wastewater and water, but very few studies are for oxidation of As [6-10]. The most characteristic chemical properties of ozone are its strong oxidizing and high standard redox potential according to the reaction conditions. It is strong oxidizing nature and its tendency to transfer an $\mathrm{O}$ atom with coproduction of $\mathrm{O}_{2}$ [4]. The standard redox potentials in acid (1) and in alkaline (2) solutions are the following reactions.

$$
\begin{aligned}
& \mathrm{O}_{3}+\mathrm{H}^{+}+2 \mathrm{e}^{-} \rightarrow \mathrm{O}_{2}+\mathrm{H}_{2} \mathrm{O} \mathrm{E}^{0}=+2.075 \mathrm{~V} \\
& \mathrm{O}_{3}+\mathrm{H}_{2} \mathrm{O}+2 \mathrm{e}^{-} \rightarrow \mathrm{O}_{2}+2 \mathrm{OH} \cdot \mathrm{E}^{0}=+1.246 \mathrm{~V}
\end{aligned}
$$

*corresponding author: e-mail: gjzhang@ipe.ac.cn DOI: http://dx.doi.org/10.5564/mjc.v17i43.741
In some cases, free radicals are formed from the ozone reaction as shown in reaction 2 . The free radicals propagate themselves through the mechanisms of elementary steps to yield hydroxyl radicals. These hydroxyl radicals are extremely reactive with any organic and inorganic [11]. Khuntia et al. have oxidized As(III) using ozone microbubbles in the $\mathrm{pH}$ range of 5-9 and the oxidation was fast at $\mathrm{pH} 6$ and slow at $\mathrm{pH}$ 7. They observed that the independent relative of $\mathrm{pH}$ in the range of 5-9 on the rate of As (III) oxidation. Therewith, the roles of $\cdot \mathrm{OH}$ radical found to be effective in the oxidation of As(III) by using 2-propanol as the $\cdot \mathrm{OH}$ radicals scavenger at $\mathrm{pH} 5$ and 6 respectively. At pH 5 and 6 , the reaction of $\mathrm{As}$ (III) likely occurred with both $\cdot \mathrm{OH}$ radical and molecular ozone [11-12]. Kim and Nriagu have shown the effectiveness of ozone on oxidation of arsenic under ambient conditions in both groundwater and samples in neutral solutions [7]. In addition, the $\mathrm{pH}$ of the solution is also important in determining the arsenic speciation. However, the exact mechanism of the $\cdot \mathrm{OH}$ radical generation under strong acidic condition is precisely not known. Li et al. investigated the generation of hydroxyl radicals by microbubbles at acidic $\mathrm{pH}$ and confirmed the generation of hydroxyl radicals at $\mathrm{pH} 2$ [13]. On the other hand, another brief description of ozone is catalytic ozonation using metalion and it is a promising method to enhance the hydroxyl generation from ozone. For example $\mathrm{Mn}(\mathrm{II})$, $\mathrm{Fe}(\mathrm{II}), \mathrm{Fe}(\mathrm{III}), \mathrm{Zn}(\mathrm{II}), \mathrm{Co}(\mathrm{II}), \mathrm{Ni}(\mathrm{II})$ and $\mathrm{Cu}(\mathrm{II})$ have identified to be of a higher catalytic ozonation efficiency than ozone alone. These metal catalysts increase the hydroxyl radical generation and the oxidation of the compound occurs both directly and indirectly [14]. Khuntia et al. have reported that

(2) hydroxyl radicals were generated by the use of $(\mathrm{Cu}(\mathrm{II}))$, and the trend was $\mathrm{Fe}(\mathrm{III})<\mathrm{Fe}(\mathrm{II})<\mathrm{Mn}(\mathrm{II})<\mathrm{Cu}(\mathrm{II})[12]$. The conversion of $\mathrm{As}(\mathrm{III})$ to $\mathrm{As}(\mathrm{V})$ by different oxidants especially with ozone is well documented except the 
oxidation of $\mathrm{As}(\mathrm{III})$ to $\mathrm{As}(\mathrm{V})$ by ozone in acidic condition. However, the significant requirement for fixation of arsenic from the As contaminated water by precipitation process is the As should be in arsenate form ( +5 state) in acidic solution. Therefore, the objective of this study is to determine the effectiveness of ozone for oxidizing As(III) to As(V) in an acidic condition. The optimal conditions have been determined including experimental temperature, $\mathrm{pH}$ of the solution, an initial concentration of $\mathrm{As}$ (III) and reaction time for oxidation of As(III). After the oxidation process, arsenic was removed by the precipitated with ferric $\left(\mathrm{Fe}^{3+}\right)$ under acidic conditions ( $\mathrm{pH}$ 1-2).

\section{EXPERIMENTAL}

Chemicals: All the reagents were of analytical grade and used without further purification. All solutions were prepared with deionized water. Ozone gas was used as oxidizing agent. Sodium arsenite $\left(\mathrm{NaAsO}_{2}\right)$ was used as the source of As(III).

Oxidation of As(III) by ozone: Ozone was produced through electronic discharge directly from an ozone generator with air. Then ozone gas was injected into the reaction mixture under stirring for mass transfer and dissolution. When the reaction takes place at $90^{\circ} \mathrm{C}$, solution was indirectly electrically heated. The Eh and $\mathrm{pH}$ of solutions were measured by Mettler Toledo FE20 and $\mathrm{EL} 20 \mathrm{pH} / \mathrm{mV}$ with dual electrode inputs. And $\mathrm{pH}$ was adjusted by adding (1:1) $\mathrm{H}_{2} \mathrm{SO}_{4}$ or $1 \mathrm{~N} \mathrm{NaOH}$. Separation of $\boldsymbol{A s}(\mathrm{III})$ and $\boldsymbol{A s}(\mathrm{V})$ : $\mathrm{As}(\mathrm{III})$ and $\mathrm{As}(\mathrm{V})$ were
Determination of arsenic concentration: Residual As(III) concentration in the solution was measured by using inductively coupled plasma atomic emission spectroscopy (ICP) (Perkin Elmer Optima 5300DV).

Experimental procedure: The source of $\mathrm{As}(\mathrm{III})$ as arsenite was prepared from $\mathrm{NaAsO}_{2}$ which was dissolved in water with different initial concentrations. An appropriate amount of arsenic (III) solution was measured and placed in the beaker and $\mathrm{H}_{2} \mathrm{SO}_{4}$ or $\mathrm{NaOH}$ was added to adjust the desired $\mathrm{pH}$ of a solution. The total volume was adjusted to $0.5 \mathrm{I}$ by adding deionized water. For the high temperature, the reaction solution was heated under stirring. When the temperature reached $95^{\circ} \mathrm{C}$, the ozone gas was injected into the mixture to start the oxidation reaction. At the set time intervals, $10 \mathrm{ml}$ of samples were taken out of the flask reactor for the profile of As. The $\mathrm{pH}$ and the Eh of each sample were measured by Mettler Toledo FE20 and $\mathrm{EL} 20 \mathrm{pH} / \mathrm{mV}$ with dual electrode inputs. The experimental equipment is described in Figure 1. The amount of oxidized As was determined by the difference between the final concentration of $A s(I I I)$ in solution and the initial concentration of As(III).

Precipitation process: The solution after oxidation was poured into the glass reactor. Then the required ferric sulfate was added with water to make the total volume $700 \mathrm{ml}$ as described by Fujita et al. [16, 17]. Then the glass reactor was heated by an indirect heater and stirred until it reached $95^{\circ} \mathrm{C}$. The air was introduced while stirring. The samples slurry was cooled to $60^{\circ} \mathrm{C}$ before measuring

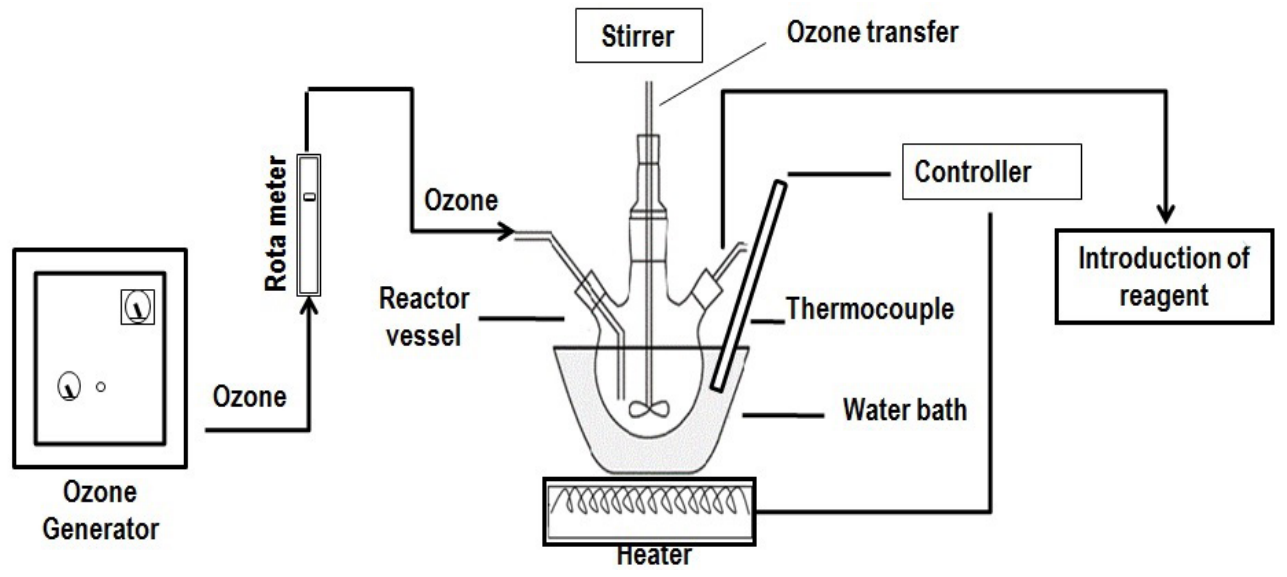

Fig.1. Schematic of the experiment setup

separated by using Analytic grade AG® $1 \times 8$ 100-200 mesh resin (acetate form) by the method described by Ficklin [15]. The resin was packed into a glass column of $10 \mathrm{~cm}$ height and $12 \mathrm{~mm}$ diameter. Before running the sample, the resin was converted into the acetate form. About $5 \mathrm{ml}$ of $0.1 \mathrm{M} \mathrm{NaOH}$ was passed through the resin, followed by $20 \mathrm{ml}$ water and $8 \mathrm{ml}$ of $1.0 \mathrm{~mol} / \mathrm{l}$ acetic acid, at a flow rate of $1.0 \mathrm{ml} \cdot \mathrm{min}^{-1}$, the mini-column was washed with $100 \mathrm{ml}$ of deionized water. Then an aqueous solution of $3 \mathrm{ml}$ containing $\mathrm{As}(\mathrm{III})$ and $\mathrm{As}(\mathrm{V})$ was passed through the column at a flow rate of $1 \mathrm{ml} \cdot \mathrm{min}^{-1}$, followed by $7 \mathrm{ml}$ deionized water. As $(\mathrm{V})$ was retained in the column while As(III) was collected from the effluent in clean sample bottles. A solution of $0.12 \mathrm{~mol} / \mathrm{l}$ of $\mathrm{HCl}$ was used to elute $\mathrm{As}(\mathrm{V})$ from the column. The eluted $\mathrm{As}(\mathrm{V})$ was collected in other flasks. After each run, the column was washed with $2.0 \mathrm{~mol} / / \mathrm{HCl}$ and then with $50 \mathrm{ml}$ water.
$\mathrm{pH}$ and Eh with time intervals. After measurement of $\mathrm{pH}$ and Eh, $10 \mathrm{ml}$ sampled slurry was passed through a $0.2 \mu \mathrm{m}$ membrane filter to separate the solid and liquid. The precipitate was washed with distilled water. All the residual solutions were collected into a $50 \mathrm{ml}$ bottle for determining the concentration of total As and As(III).

\section{RESULTS AND DISCUSSION}

Effect of reaction time: The effect of reaction time on oxidation of $\mathrm{As}(\mathrm{III})$ with ozone at $\mathrm{pH} 1$ and $20^{\circ} \mathrm{C}$ is shown in Figure 2. The ozone oxidation was effective in an acidic solution and the concentration of As(III) decreased whereas the concentration of $\mathrm{As}(\mathrm{V})$ increased in the solution after oxidation. $60 \%$ of $5 \mathrm{~g} / \mathrm{l} \mathrm{As}$ (III) oxidized below $10 \mathrm{~min}$ and more than $99 \%$ of $\mathrm{As}(\mathrm{III})$ was oxidized within $25 \mathrm{~min}$ in an acidic solution. 


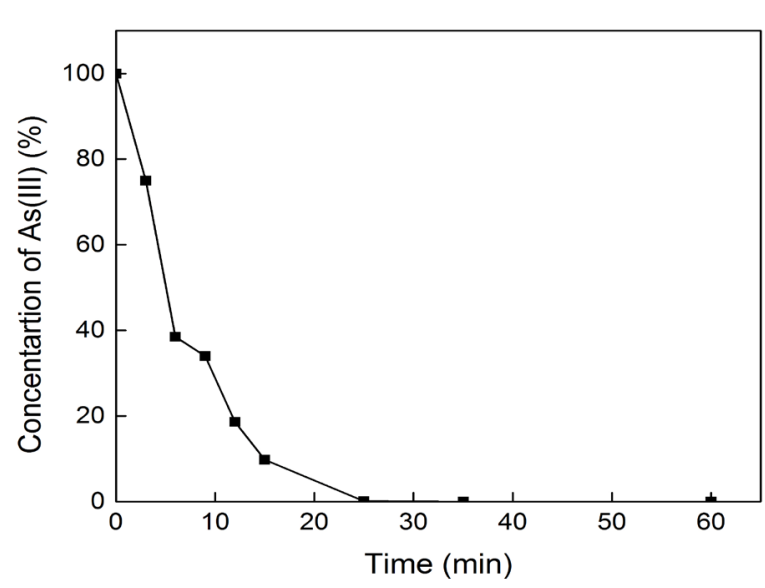

Fig. 2. Effect of oxidation time at low initial concentration $(50 \mathrm{mg} / \mathrm{l}), \mathrm{pH} 1$ and $\mathrm{T}-20^{\circ} \mathrm{C}$

Fig.3. illustrates the function of oxidation time at three different initial concentrations of As(III). The results are the three identical experiments performed at the same conditions. The amount of oxidized As(III) in the solution decreased to less than $0.0001 \mathrm{~g} / \mathrm{l}$ when the reaction time is $120 \mathrm{~min}$ at $5 \mathrm{~g} / \mathrm{l}$, about $90 \mathrm{~min}$ at $2.5 \mathrm{~g} / \mathrm{l}$ and $75 \mathrm{~min}$ at $1.5 \mathrm{~g} / \mathrm{l}$ with the initial $\mathrm{pH}$ of 0.5 (acidic media). These results show that the oxidation of $\mathrm{As}(\mathrm{III})$ with ozone is quite dependent on the reaction time.

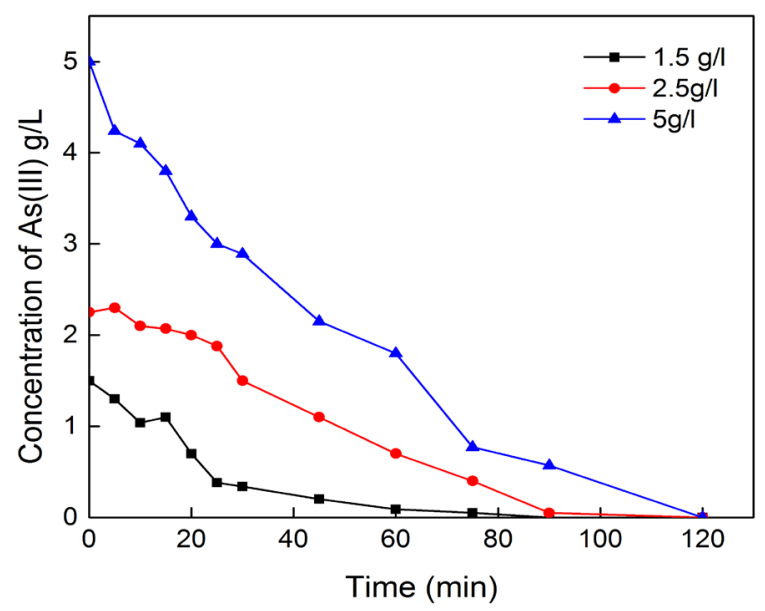

Fig. 3. Oxidation of $A s(I I I)$ to $A s(V)$ with different initial concentrations $\left(\mathrm{pH} 0.5,20^{\circ} \mathrm{C}\right)$

Effect of initial $\mathrm{pH}$ of the solution: The unique feature of ozone is its decomposition in an aqueous solution. $\mathrm{pH}$ is one of the most important factors for the ozone decomposition and controlling arsenic speciation in aqueous systems [18]. In this study, the batch experiment results indicate that the ozone is very effective on the oxidation of As(III) at $\mathrm{pH}$ from 0.5 to 2 . When the $\mathrm{pH}$ of the solution was $0.5,50$ $\mathrm{mg} / \mathrm{l}$ As(III) was completely oxidized in $20 \mathrm{~min}$ as shown in Figure 2. The final $\mathrm{pH}$ values of solutions, after the oxidation reactions were slightly lower than that initial $\mathrm{pH}$ values of solutions. For example, when initial $\mathrm{pH}$ was 0.5 , the final $\mathrm{pH}$ reached 0.34 in 120 minutes.

Figure 4. shows that the effect of initial pH on the ozone oxidation of As(III) at ambient temperature. Under this condition, about $99 \%$ of As (III) was completely oxidized in 35 minutes. The oxidation was similar at both $\mathrm{pH}$ 1 and $\mathrm{pH}$ 2. It can be interpreted by direct and indirect reaction mechanisms [19-21]. The reaction of As(III) with $\cdot \mathrm{OH}$ radicals forms the $\mathrm{As}(\mathrm{IV})$ intermediate, which further oxidizes $\mathrm{As}(\mathrm{III})$ to $\mathrm{As}(\mathrm{V})$. The reaction mechanism is speculated as follows [5, 22, 23].

$$
\begin{aligned}
& \mathrm{As}(\mathrm{III})+\mathrm{OH} \rightarrow \mathrm{As}(\mathrm{IV}) \\
& \mathrm{As}(\mathrm{IV})+\mathrm{O}_{2} \rightarrow \mathrm{As}(\mathrm{V})+\mathrm{O}_{2} \cdot{ }^{-}
\end{aligned}
$$

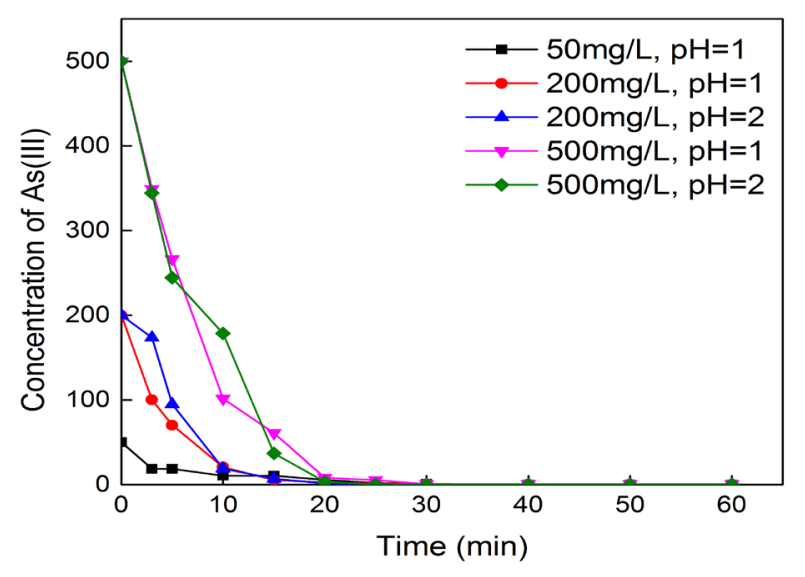

Fig. 4. Effect of $\mathrm{pH}$ on $\mathrm{As}(\mathrm{III})$ oxidation with ozone at $20^{\circ} \mathrm{C}$

Effect of temperature and $\mathrm{Fe}^{3+}$ : In our work, the experiment was carried out for testing the effect of temperature on oxidation of As(III) with ozone in an acidic solution at its low $(50 \mathrm{mg} / \mathrm{l})$ and high initial $(5 \mathrm{~g} / \mathrm{l})$ concentrations. Experiment results show that at $25^{\circ} \mathrm{C}$ the ozone oxidation was efficient but at $90^{\circ} \mathrm{C}$ there was no difference in the concentration of $\mathrm{As}(\mathrm{III})$ in the solutions between initial and after reactions at $\mathrm{pH} 1$ and 2 as shown in Table 1 in absence of $\mathrm{Fe}^{3+}$. Whereas, in presence of $\mathrm{Fe}^{3+}, 5 \mathrm{~g} / \mathrm{l} \mathrm{As}(\mathrm{III})$ was oxidized $97.2 \%$ and $90.6 \%$ at $\mathrm{pH} 2$ and 1 , respectively, in 2 hours as shown in table 1, which depicts the comparison of the presence and absence of $\mathrm{Fe}^{3+}$ on the oxidation of $\mathrm{As}(\mathrm{III})$.

During ozonation of aqueous solution, part of the ozone normally decomposes to $\mathrm{OH}$ radicals. The elementary reaction mechanism of decomposition of ozone in aqueous solution is as follows.

$$
\begin{aligned}
& \mathrm{O}_{3}+\mathrm{OH}^{-} \rightarrow \mathrm{HO}_{2}^{-}+\mathrm{O}_{2} \\
& \mathrm{O}_{3}+\mathrm{HO}_{2}^{-} \rightarrow \mathrm{OH}^{-}+\mathrm{O}_{2} \cdot{ }^{-}+\mathrm{O}_{2}
\end{aligned}
$$

The radicals that are produced during reaction (6) can introduce other reactions with ozone, causing more $\mathrm{OH}$ radicals to be formed [4]. On the other hand, metal catalysis increases the hydroxyl radical generation from ozone in aqueous solution. Several effectual reports suggested the catalytic oxidation reactions [11-14]. Khuntia et al. (2013) determined the enhancement of $\mathrm{OH}$ - radical generation from ozone for the catalytic ozonation using four common metal ions. In their findings, the catalytic ozonation was more efficient than that the ozonation alone by increasing $\mathrm{OH} \cdot\left(\mathrm{O}_{3}<\mathrm{O}_{3}+\mathrm{Fe}(\mathrm{III})<\mathrm{O}_{3}+\mathrm{Fe}(\mathrm{II})<\mathrm{O}_{3}+\mathrm{Mn}(\mathrm{II})<\mathrm{O}_{3}+\mathrm{Cu}(\mathrm{II})\right)$. Also, many researchers have been determined that the $\mathrm{Fe}(\mathrm{III})$ catalytic ozonation was more effective in degradation of organic and inorganic compounds than the ozone alone, due to the generation of $\mathrm{OH}$. radicals $[5,8,12,24,28]$.

$$
\begin{aligned}
& \mathrm{Fe}^{3+}+\mathrm{O}_{3}+\mathrm{H}_{2} \mathrm{O} \rightarrow \mathrm{FeO}^{2+}+\mathrm{H}^{+}+\mathrm{OH}^{-}+\mathrm{O}_{2} \\
& \mathrm{FeO}_{2}++\mathrm{H}_{2} \mathrm{O} \rightarrow \mathrm{Fe}^{3+}+\mathrm{OH} \cdot+\mathrm{OH}^{-}
\end{aligned}
$$


The reaction mechanism for the oxidation of $\mathrm{As}$ (III) by $\mathrm{OH}$. described by Hoigne et al.

$$
\begin{aligned}
& \mathrm{As}(\mathrm{III})+\mathrm{OH} \cdot \rightarrow \mathrm{As}(\mathrm{IV}) \\
& \mathrm{As}(\mathrm{IV})+\mathrm{O}_{2} \rightarrow \mathrm{As}(\mathrm{V})+\mathrm{O}_{2} .
\end{aligned}
$$

Therefore, the generation of hydroxyl radicals by the $\mathrm{Fe}^{3+}$ catalyst increase the oxidation of $\mathrm{As}(\mathrm{III})$. So it can be hypothesized that the existence of $\mathrm{Fe}^{3+}$ in the ozonation process increases the efficiency of $\mathrm{As}$ (III) oxidation at $90^{\circ} \mathrm{C}$ in an acidic solution.

\section{CONCLUSIONS}

In our study, we aimed to determine the conversion of As(III) to $\mathrm{As}(\mathrm{V})$ by ozone oxidation under acidic conditions and showed ozone is a strongest oxidant. The experimental results illustrate that the oxidation of $\mathrm{As}(\mathrm{III})$ in the acidic solution by ozone was fast. The $\mathrm{pH}$ values of solutions were slightly decreased after the ozonation process and temperature was quite dependent on oxidation reaction. At increased temperature $\left(90^{\circ} \mathrm{C}\right)$ ozone was not effective on As(III) oxidation however, in presence of ferric ions, ozone oxidation reaction of $\mathrm{As}(\mathrm{III})$ was effective at $90^{\circ} \mathrm{C}$.

Table 1. Effect of $\mathrm{Fe}$ (III) on oxidation of As(III)

\begin{tabular}{ccccccc}
\hline \multirow{2}{*}{ Reactions } & \multicolumn{4}{c}{ Reaction conditions } & \multicolumn{2}{c}{ As(III) in the solution g/l } \\
\cline { 2 - 7 } & $\mathrm{pH}$ & Time & $\mathrm{T}^{\circ} \mathrm{C}$ & Eh $(\mathrm{mV})$ & Initial & After reaction \\
\hline \multirow{2}{*}{ Presence $\mathrm{Fe}(\mathrm{III})$} & 2 & & & 646 & & 0.12 \\
& 1 & \multirow{2}{*}{$2(\mathrm{~h})$} & \multirow{2}{*}{$90^{\circ} \mathrm{C}$} & 660 & $5 \mathrm{~g} / \mathrm{l}$ & 0.47 \\
Absence $\mathrm{Fe}(\mathrm{III})$ & 2 & & & 391 & & 5.03 \\
& 1 & & & 491 & & 5.007 \\
\hline
\end{tabular}

Table 2. Oxidation and precipitation of As

\begin{tabular}{lccccccc}
\hline After reactions & \multicolumn{5}{c}{ Reaction conditions } & \multicolumn{3}{c}{ As concentration in the solution (g/l) } & Removed As g/l \\
\cline { 2 - 6 } & $\mathrm{T}^{\circ} \mathrm{C}$ & Time & $\mathrm{Eh}(\mathrm{mV})$ & $\mathrm{pH}$ & Total & As(III) & \\
\hline Oxidation & 25 & $2(\mathrm{~h})$ & 446 & 2 & 5.250 & 1.004 & - \\
Precipitation & 90 & $5(\mathrm{~h})$ & 900 & 2 & 0.271 & 0.27 & 4.98 \\
\hline
\end{tabular}

Once the effectiveness of $\mathrm{Fe}^{3+}$ in oxidation process with As(III) has been identified, the precipitation process of As occurred according to the operational procedures for the ferric arsenate (scorodite) precipitation [16, 17, 25].

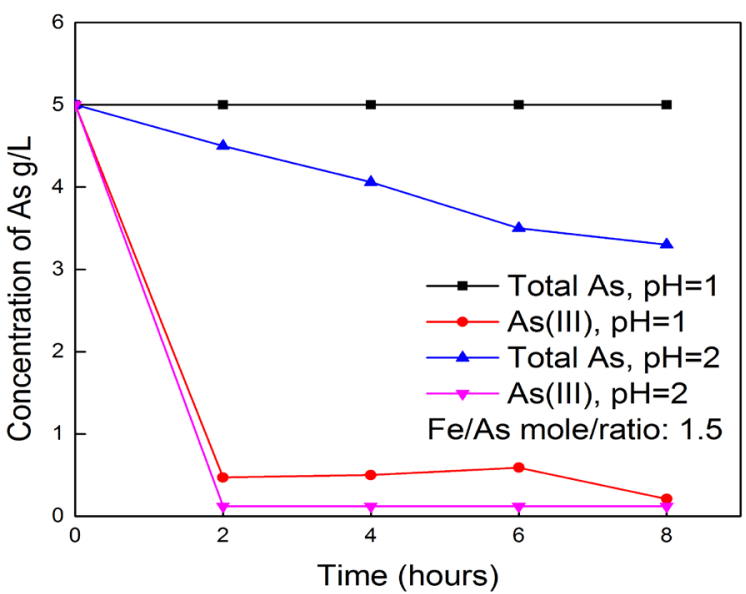

Fig. 5. Effect of $\mathrm{Fe}^{3+}$ on oxidation of $\mathrm{As}$ (III) $(5 \mathrm{~g} / \mathrm{l})\left(\mathrm{T}-90^{\circ} \mathrm{C}\right)$

As shown in Figure 5, with the increase in the reaction time at $\mathrm{pH} 2,97.6 \%$ of $5 \mathrm{~g} / \mathrm{As}(\mathrm{III})$ and $35 \%$ of total As were removed from the solution in 8 hours. At pH 1, 95.8\% of $5 \mathrm{~g} / \mathrm{l}$ As was oxidized in 8 hours but the solid products did not form.

The precipitation test of As with the addition of $\mathrm{Fe}_{2}\left(\mathrm{SO}_{4}\right)_{3}$ at $\mathrm{pH} 2$ and $90^{\circ} \mathrm{C}$ was carried out after oxidation reaction of $\mathrm{As}(\mathrm{III})$ to $\mathrm{As}(\mathrm{V})$ at $25^{\circ} \mathrm{C}$. The result is shown in Table 2 . $0.27 \mathrm{~g} / \mathrm{I} \mathrm{As}$ (III) was in the residual solution, for As(III) is not absorbed the surface of $\mathrm{FeO}(\mathrm{OH})[9,26,27]$.
Therefore $\mathrm{Fe}^{3+}$ might be acting as a catalyst in the oxidation of As(III) by ozone due to the use of metal ion catalysts increase the hydroxyl radical generation in ozonation reaction. After the oxidation process with additional $\mathrm{Fe}_{2}\left(\mathrm{SO}_{4}\right)_{3}$ for 7-8 hours, more than $90 \% \mathrm{As}$ (III) was removed from the solution. Insofar as ozone has been found to be effective for the oxidation of As(III) under acidic condition, As can be removed by producing crystalline scorodite.

ACKNOWLEDGEMENTS: The authors acknowledge 973 Program (2013CB632601), the National Natural Science Foundation of China $(21576271,21427814)$ and Jiangsu Synergetic Innovation Center for Advanced Biomanufacturing and Materials.

\section{REFERENCES}

1. Smedley P.L., Kinniburgh G.D. (2005) Arsenic in groundwater and the environment. In: Selinus O., Alloway B., Centeno J.A., Finkelman R.B., Fige R. et al. Essentials of Medical Geology: Impacts of the natural environment on public health. Amsterdam; London, UK, Elsevier, 263-299

2. Cullen W.R., Reimar K.J. (1989) Arsenic speciation in the environment. Chem. Rev. 89, 713-764.

3. Sulivan C., Tyrer M., Cheeseman C.R., Nigel J.D. Graham. (2010) Disposal of water treatment wastes containing arsenic a review. Sci. Total. Environ. 408, 1770-1778.

4. Greenwood N.N., Earnshaw A. (1997) Chemistry of the Elements, second Ed., School of Chemistry University of Leeds, U.K.

5. Hug S.J., Leupin O. (2003) Iron-catalyzed oxidation of arsenic (III) by oxygen and by hydrogen peroxide: 
$\mathrm{pH}$-dependent formation of oxidants in the Fenton reaction. Environ. Sci. Technol. 37, 2734-2742

6. Khuntia S., Majumder S.K., Ghosh P. (2014) Oxidation of $\mathrm{As}(\mathrm{III})$ to $\mathrm{As}(\mathrm{V})$ using ozone microbubbles. Chemosphere, 97, 120-124.

7. Kim M., Nriagu J. (2000) Oxidation of arsenite in groundwater using ozone and oxygen. Sci. Total. Environ., 247, 71-79.

8. Souza A.L., Filho H.J.I., Peixoto A.L.C., Guimarães O.L.C., Loures C.C.A., et al. (2013) Effects of ferric ions on the catalytic ozonation process on sanitary landfill leachates. Ambi-Agua, 8, 48-61.

9. Harris B. (2003). The removal of arsenic from process solutions: Theory and industrial practice. Hydrometallurgy 2003, Proceedings of the $5^{\text {th }}$ International Symposium Honoring Professor lan Ritchie, Editors. Young C., Alfantazi A., Anderson C., James A., Dreisinger D., Harris B, Vancouver, British Columbia, Canada, 1889-1902.

10. Papassiopi N., Vircikova E., Nenov V., Kontopoulos A., Molnar L. (1996) Removal and fixation of arsenic in the form of ferric arsenates. Three parallel experimental studies. Hydrometallurgy, 41, 243-253.

11. Khuntia S., Kumar S.M., Ghosh P. (2013) Removal of Ammonia from water by ozone microbubbles. Ind. Eng. Chem. Res., 52, 318-326.

12. Khuntia S., Majudar S.K., Ghosh P. (2016) Catalytic ozonation of dye in a microbubble system: hydroxyl radical contribution and effect of salt. J. Environ. Chem. Eng., 4, 2250-2258.

13. Li P., Takahashi M., Chiba K. (2009) Enhanced freeradical generation by shrinking microbubbles using copper catalyst. Chemosphere., 77, 1157-1160.

14. Hoigne J., Bader H. (1975). The role of hydroxyl radical reactions in ozonation processes in aqueous solutions. Water Res., 10, 377-386.

15. Ficklin W.H. (1983) Separation of arsenic(III) and arsenic $(\mathrm{V})$ in ground waters by ion exchange. Talanta , 30, 371-373.

16. Fujita T., Taguchi R., Abumiya M., Matsumoto M., Shibata E. et al. (2008) Novel atmospheric scoroditesynthesis by oxidation of ferrous solution Part I. Hydrometallurgy, 90, 92-102.

17. Fujita T., Taguchi R., Abumiya M., Matsumoto M., Shibata E., et al. (2008) Novel atmospheric scorodite synthesis by oxidation of ferrous sulfate solution. Part II. Effect of temperature and air. Hydrometallurgy, 90, 85-91.
18. Wu C.H., Kuo C.Y., Chang C.L. (2008) Homogeneous catalytic ozonation of C.I. Reactive Red 2 by metallic ions in a bubble column reactor. J. Hazard.Mater., 154, 748-755.

19. Leupin O.X., Hug J.S. (2005) Oxidation and removal of arsenic (III) from aerated groundwater by filtration through sand and zero-valent iron. Water Res., 39, 1729-1740.

20. Beltran F.J. (2005) Ozone reaction kinetics for water and wastewater systems. Book

21. Takahashi M., Chiba K., Li P. (2007) Formation of hydroxyl radicals by collapsing ozone microbubbles under strongly acidic conditions. J. Phys. Chem., 111, 11443-11446.

22. Eriksson M. (2005) Ozone chemistry in aqueous solution -Ozone decomposition and stabilization. Licentiate Thesis, Department of Chemistry Royal Institute of Technology Stockholm, Sweden.

23. Gunten V.U. (2003) Ozonation of drinking water: Part I. Oxidation kinetics and product formation. Water Res., 37, 1443-1467.

24. Zhu X., Xu X. (2004) The mechanism of Fe(III) catalyzed ozonation of phenol. J. Zhejiang. Univ. Sci., 5(12), 1543-1547

25. Gomez M.A., Becze L., Cutler N.J., Demopoulos G.P. (2011) Hydrothermal reaction chemistry and characterization of ferric arsenate phases precipitation from $\mathrm{Fe}_{2}\left(\mathrm{SO}_{4}\right)_{3} \quad-\mathrm{As}_{2} \mathrm{O}_{5} \quad-\mathrm{H}_{2} \mathrm{SO}_{4}$ solutions. Hydrometallurgy, 107, 74-90.

26. Jia Y., Demopoulos G.P. (2008) Coprecipitation of arsenate with iron(III) in aqueous sulfate media: Effect of time, lime as base and co-ions on arsenic retention. Water Res., 42, 661-668.

27. Berre J.F.L., Gauvin R., Demopoulos G.P. (2007) Characterization of poorly-crystalline ferric arsenate precipitated from equimolar $\mathrm{Fe}(\mathrm{III})$ - $\mathrm{As}(\mathrm{V})$ solutions in the $\mathrm{pH}$ range 2 to 8 . Metall. Mater. Trans., 38B, 751-766.

28. Kocar B.D. and Inskeep W.P., (2003). Photochemical oxidation of $\mathrm{As}(\mathrm{III})$ in Ferrioxalate solution. Environ. Sci. Technol., 37, 1581-1588.

29. Hoigne J., Bader H., Haag W.R., Staehelin J. (1985) Rate constants of reactions of ozone with organic and inorganic compounds in water-III. Inorganic compounds and radicals. Water Res., 19, 993-1004. 